Creative Commons User License: CC BY-NC-ND

Abstracted by: EBSCOhost, Electronic Journals Service (EJS),

Google Scholar, Journal Seek, Scientific Commons,

Food and Agricultural Organization (FAO), CABI and Scopus

http://eoi.citefactor.org/10.11226/v24i2
Journal of Agricultural Extension

Vol. 24 (2) April, 2020

ISSN(e): 24086851; ISSN(Print); 1119944X

http://journal.aesonnigeria.org

http://www.ajol.info/index.php/iae

Email: editorinchief@aesonnigeria.org

\title{
Socio- Economic Characteristics of Urban Extension Workers Influencing Empowerment of Farmers in Nairobi County, Kenya
}

https://dx.doi.org/10.4314/jae.v24i2.7

\author{
Mwaura, Mary Njoki \\ Department of Food, Agriculture and Forestry \\ Nairobi City County. \\ E-mail:mnjokimwaura06@gmail.com \\ Telephone: +254-721865717
}

\author{
Sabina Mukoya - Wangia \\ Department of Agricultural Economics \\ University of Nairobi. \\ E-mail: sm.wangia@gmail.com \\ Telephone: +254-733878658 \\ Origa, Japheth Ododa \\ Department Education, Communication and Technology \\ University of Nairobi. \\ E-mail: odadaoriga@uonbi.ac.ke \\ Telephone: +254-720468607 \\ Oliver, Lee Ernest Mbatia \\ E-mail:profmbatia@yahoo.co.uk \\ Telephone: +254-722831316
}

\section{Abstract}

The study examined the influence of socio-economic characteristics of urban extension workers on farmers' empowerment. Purposive and simple random sampling methods were used to select 64 extension workers by utilizing the Yamane formula. Data were collected by the use of questionnaires. Frequencies, percentiles and multiple linear regressions were utilised to analyse the data. The extension workers' socio - economic characteristics were found to positively influence the choice of extension methods. The findings revealed that $37.2 \%$ of farmer empowerment could be explained by the choice of extension methods influenced by the characteristics of extension workers. However, $49.9 \%$ of the extension workers were not aware of the adult learning principles (ALPS) that are employed in the appropriate choice of extension methods. The study recommends that extension workers in Nairobi County be trained in competencies to consider ALPS and information communication and technology (ICT) techniques in choices of extension methods. These competencies can ultimately lead to an extension system design transformation that will assist the few extension workers to serve more farmers efficiently and effectively leading to farmer empowerment. 
Creative Commons User License: CC BY-NC-ND

Abstracted by: EBSCOhost, Electronic Journals Service (EJS),

Google Scholar, Journal Seek, Scientific Commons,

Food and Agricultural Organization (FAO), CABI and Scopus

http://eoi.citefactor.org/10.11226/v24i2
Journal of Agricultural Extension

Vol. 24 (2) April, 2020

ISSN(e): 24086851; ISSN(Print); 1119944X

http://journal.aesonnigeria.org

http://www.ajol.info/index.php/iae

Email: editorinchief@aesonnigeria.org

Key words: Extension worker characteristics, farmer empowerment, Nairobi, urban and peri-urban agriculture.

\section{Introduction}

Urban agriculture is the growing of plants and rearing of livestock within and around the cities on a small scale for domestic purposes and sale of surplus. Peri-urban agriculture is larger and commercially oriented depending on the context according to Taguchi and Santini, (2019). In most cities including Nairobi, urban and peri-urban agriculture (UPA) provides food security to the households, provides income and reduces food expenditure. It contributes one fifth to two thirds of total household food supply (Chihambakwe, Mafongoya and Obert, 2018). UPA also provides a lifeline to urban farmers in times of political, economic and environmental crisis.

In Nairobi County, UPA activities are diminishing due to severe competition from other city activities such as the escalating buildings, which has contributed to a reduction of urban agricultural land. Other major challenges include inadequate inputs and limited extension services to the city farmers. The city experiences nonspecific policies to address issues on competition of resources such as land, water, credit and labour (Mbugua, 2018). The urban farmer is not adequately empowered to make decisions on their farming systems to deal with the challenges for a profitable and sustainable UPA. The main stakeholders in the UPA system include the county government that is the main employer of the agricultural extension workers, nongovernmental organisations, community-based organisations and the private sector.

An extension system consists of the interconnectedness between the extension workers, the farmers, the farm environment and the logistics which include the extension methods used for information dissemination. Extension effectiveness and efficiency in performance depends on an enabling political, social, economic, technological and legal environment (Ministry of Agriculture Livestock and Fisheries (MOALF), 2017). The competences of an extension worker to balance these diverse situations are dependent on the influence of the worker's socio-economic characteristics.

For effective service delivery, the extension worker should be able to identify, categorize, choose and employ adequate extension methods to the clients in terms of enterprise adopted, level of knowledge and skills and resources available (MOALF, 2017). This categorization should be done by the extension worker as opposed to being dictated by the programme.

In Kenya, public extension services were well staffed in the 1980s, well facilitated and distributed up to the location levels. Extension services were complemented by functional farmers training centres which held regular farmers' trainings country wide. However, extension staffing and facilitation has continued to decline due to a government freeze in staff employment leading to low staff numbers. This has led to the current staff farmer ratio of approximately 1:1,500 in Nairobi compared to the desired level of 1:400 which has affected spatial coverage (Mbugua, 2018). 
Creative Commons User License: CC BY-NC-ND

Abstracted by: EBSCOhost, Electronic Journals Service (EJS), Google Scholar, Journal Seek, Scientific Commons,

Food and Agricultural Organization (FAO), CABI and Scopus
Journal of Agricultural Extension

Vol. 24 (2) April, 2020

ISSN(e): 24086851; ISSN(Print); 1119944X

http://journal.aesonnigeria.org

http://www.ajol.info/index.php/iae

Email: editorinchief@aesonnigeria.org

Agricultural services were devolved to the counties in 2013, causing a decline in the work force and affecting efficiency and effectiveness of the services and the staff farmer ratio. The current characteristics of extension methods in Nairobi include, farmer demand driven services, participatory services, individual, groups, and mass media methods as well as networking and collaborations (Nairobi County Integrated Development Plan (NCIDP), 2018).

Farmers and clients are reached through individual methods of farm visits and office visits. ICT as an extension method is not well established. Group methods include training, demonstrations and group tours while mass methods include field days, exhibitions, and distributions of print materials. Trainings and demonstrations at the show ground during the Nairobi international trade fair (show) is also used to pass information, (NCIDP, 2018).

The extension worker job performance is influenced by the personality of the extension worker which is a result of genetic and environmental influence according to (Ijioma and Adescope, 2015). Among the socio-economic characteristics that affect personality are gender, age, educational levels and work experiences of the extension worker.

According to (Suvedi and Kaplowitz, 2016) the role of the extension worker must go through a transformation from technology transfer to facilitation in order to keep up with the changing social dynamics and empower farmers for change. However, the influence of extension worker characteristics of age, educational levels, gender and years of work experience on the choice of extension methods for empowerment of urban and peri-urban farmers in Nairobi County has not been fully investigated.

The empowerment of the Nairobi County urban farmers, in a complex environment with scarce resources, inadequate policies and legal requirements has been a challenge to the extension workers. The Nairobi County Government provides limited extension services to UPA farmers due to a freeze in staff employment causing a shortage of extension workers. The few extension workers operate on limited resources and these combined with the struggles of their personal socio-economic characteristics affect efficient service delivery to the farmers. This influences the choice of extension methods used by the extension workers resulting in inefficiency and inadequacy to empower the dynamic urban farmer to make appropriate changes in their farming systems for sustainability.

The purpose of the study was to provide basic data for a broad understanding of the Nairobi City County extension workers socio-economic characteristics and their influence on the choice of extension methods and consideration of ALPs for empowerment of urban and peri urban farmers.

\section{Methodology}

The study was conducted in Nairobi City County which is the capital and Kenya's largest City. It is located between latitudes $-1.286389 \mathrm{~S}$., longitudes $36.817223 \mathrm{E}$. and lies at an altitude of 1,798 metres above sea level (Nairobi County Annual 
Creative Commons User License: CC BY-NC-ND

Abstracted by: EBSCOhost, Electronic Journals Service (EJS), Google Scholar, Journal Seek, Scientific Commons,

Food and Agricultural Organization (FAO), CABI and Scopus
Journal of Agricultural Extension

Vol. 24 (2) April, 2020

ISSN(e): 24086851; ISSN(Print); 1119944X

http://journal.aesonnigeria.org

http://www.ajol.info/index.php/iae

Email: editorinchief@aesonnigeria.org

Development Plan (NCADP, 2018). The GPS coordinates are 1017'11, 0004" S. and $36^{\circ} 49^{\prime 2} 2.0028^{\prime \prime} \mathrm{E}$. The 2019 census indicated the county population as 4,397,073 million (Kenya National Bureau of Statistics (KNBS), 2019) with a projection of $5,433,002$ million in 2020 according to the (NCIDP), 2018). Nairobi occupies an area of about $696 \mathrm{~km}^{2}$ and experiences a temperate to tropical climate with two rainy seasons favourable for farming (NCIDP, 2018). The study was conducted in 13 purposively selected sub counties as representatives of the 17 sub counties of Nairobi. Purposive sampling of the area was utilized in order to identify the sub counties with the highest numbers of urban and peri-urban farmers and extension workers to assist the researcher to collect relevant data (Etikan, Musa and Alkassim, 2015). These were urban areas of Starehe, Mathare, Makadara, Roysambu, Kibra, Embakasi West, Embakasi Central and Embakasi South, while peri-urban areas were Dagoretti North and Dagoretti South, Kasarani, Westlands, and Langata.

The study utilized a cross-sectional survey design to assist the researcher to gather relevant information at that specific point in time (Omair, 2016) on the influence of extension worker characteristics on farmer empowerment on UPA.

Nairobi County has 187 extension workers (NCIDP, 2018). The study utilised the Yamane formula Yamane (1967 cited in Dika, Masawe, Iddi and Rumanyika, 2017) described below to achieve a sample size of 64 agricultural extension workers promoting the uptake of UPA in Nairobi County.

$n=\frac{N}{1+N\left(e^{2}\right)} \quad$ Where: $\mathrm{n}=$ sample size, $\mathrm{N}=$ population size, $\mathrm{e}=$ margin error

Yamane (1967 cited in Dika, Masawe, Iddi and Rumanyika, 2017)

The social-economic characteristics (age, gender, educational level, and experience) of the extension workers were measured categorically. Each of the 64 extension workers (13 males and 51 females) were asked to choose a favourite extension method among the categories (individual, group and mass media methods). They would then reveal the number of ALPs (flexibility, consideration of experiences, provision of solutions, lifelong learning, considerations for partnerships and provision for satisfactions) considered for each method as a contributor to empowerment of farmers.

Data were analysed with the IBM-SPSS Statistics software version 21 and inference made at $5 \%$ level of significance. Frequencies, percentiles and multiple linear regressions were used to summarize the data. Multiple linear regressions model was used to analyze the objective in order to explain the influence of the extension worker characteristics on farmer empowerment. The dependent variable was a calculated empowerment score derived from the number of ALPs that the extension worker was aware of and applied for each extension method.

The study applied the following regression equation

$$
Y=a+b 1 \text { age }+b 2 \text { gender }+b 3 \text { education }+b 4 \text { experiance }
$$


Creative Commons User License: CC BY-NC-ND

Abstracted by: EBSCOhost, Electronic Journals Service (EJS), Google Scholar, Journal Seek, Scientific Commons,

Food and Agricultural Organization (FAO), CABI and Scopus

http://eoi.citefactor.org/10.11226/v24i2
Journal of Agricultural Extension

Vol. 24 (2) April, 2020

ISSN(e): 24086851; ISSN(Print); 1119944X

http://journal.aesonnigeria.org

http://www.ajol.info/index.php/iae

Email: editorinchief@aesonnigeria.org

\section{Results and Discussions}

\section{Extension Worker Socio-Economic Characteristics and Choices of Extension Methods.}

The choice of extension methods by sex indicated that male and female workers preferred to use different methods. Table 1 shows that more male workers (62\%) chose to use farm visits as compared to $35 \%$ of female workers.

\section{Choice of Extension Methods by Sex of the Extension Worker.}

The choices of extension methods were disaggregated by sex as indicated in Table 1

Table 1: Choice of extension methods by sex of extension worker.

\begin{tabular}{lcc}
\hline & $\begin{array}{c}\text { Male } \\
\text { Percentage }(\mathbf{n}=\mathbf{1 3})\end{array}$ & $\begin{array}{c}\text { Female } \\
\text { Percentage }(\mathbf{n}=\mathbf{5 1})\end{array}$ \\
\hline Farm visits & 62 & 35 \\
Office visits & 23 & 32 \\
ICT & 15 & 33 \\
Trainings and demos & 44 & 63 \\
Group tours & 46 & 37 \\
Field days & 15 & 65 \\
Print media & 54 & 25 \\
Shows & 31 & 10 \\
\hline Source Field Survey
\end{tabular}

Source: Field Survey, 2017.

Preferences of ICT indicated that few male workers (15\%) preferred ICT as compared to female workers (33\%). However female workers were comfortable to use all three individual methods.

In the case of group methods, male workers used trainings /demonstrations (44\%) and group tours and visits (45\%). Female workers preferred to use trainings and demonstrations $(63 \%)$ as compared to tours and visits $(37 \%)$. The majority of male workers (54\%) chose print media as a mass media method while $65 \%$ of female workers chose field days.

Information communication technology was not a preferred method of extension by both male and female workers which could be related to inadequacy in skills and lack of ICT gadgets. Extension workers preferred the common methods which they were familiar with and which they mainly used in the rural areas.

The findings of Lamontagne-Godwin et al., (2019) indicated that male workers view male and female farmer's access to information differently by believing that male farmers have access to all information sources while female farmers do not. This varied belief of male workers would ultimately influence information dissemination in a county where $80 \%$ of the workers are female. 
Creative Commons User License: CC BY-NC-ND

Abstracted by: EBSCOhost, Electronic Journals Service (EJS), Google Scholar, Journal Seek, Scientific Commons,

Food and Agricultural Organization (FAO), CABI and Scopus
Journal of Agricultural Extension

Vol. 24 (2) April, 2020

ISSN(e): 24086851; ISSN(Print); 1119944X

http://journal.aesonnigeria.org

http://www.ajol.info/index.php/iae

Email: editorinchief@aesonnigeria.org

\section{Choice of Extension Methods by Age of Extension Worker}

The choice of extension methods by age are indicated in Table 2. The younger workers (31-40) preferred ICT, tours, visits and print media as extension methods. The older extension workers chose to use farm visits, trainings and demonstrations and field days. These choices could be influenced by the change in technology and also the entrant of younger farmers in urban and peri urban agriculture. The older workers preferred to use the more familiar methods as opposed to ICT.

Table 2: Disaggregation of age of the extension workers and choices of extension methods

\begin{tabular}{lclll}
\hline & $\begin{array}{l}31-40 \text { years } \\
\text { Percentage } \\
\mathrm{n}=9\end{array}$ & $\begin{array}{c}41-50 \text { years } \\
\text { Percentage } \\
\mathrm{n}=16\end{array}$ & $\begin{array}{l}>50 \text { years } \\
\text { Percentage } \\
\mathrm{n}=39\end{array}$ & $\begin{array}{c}\text { Total } \\
\text { Percentage } \\
\mathrm{n}=64\end{array}$ \\
\hline $\begin{array}{l}\text { Staff choice for individual methods } \\
\text { Farm visits }\end{array}$ & & & \\
Office visits & 0.0 & 31.0 & 49.0 & 40.6 \\
ICT & 89.0 & 31.0 & 39.0 & 30.1 \\
Staff choice for group methods & 38.0 & 12.0 & 29.7 \\
Trainings and demos & 11.0 & 81.0 & 64.0 & 60.0 \\
Group tours & 89.0 & 19.0 & 36.0 & 40.0 \\
Staff choice for mass methods & & & \\
Field days & 22.0 & 38.0 & 69.0 & 55.0 \\
Print media & 56.0 & 38.0 & 23.0 & 31.0 \\
Show & 22.0 & 24.0 & 8.0 & 14.0 \\
\hline
\end{tabular}

Source: Field Survey, 2017.

Results also show that middle aged workers (41-50) worked efficiently with both modern methods and the traditional methods. This could be due to work experiences which has provided an understanding of the farmers and a positive effect on work performance. These results concur with (Malgorzata, 2017) indicating that abilities to work differs among individuals and is therefore difficult to ascertain when performance declines with age due to mental and physical changes. Results also agree with Oluwafemi, Olorunfemi and Oladele, (2019) who indicated that officers in the age of 25-45 years were more active, experienced and suited for extension work.

\section{Choice of Extension Methods by Educational Levels of the Extension Worker}

The choice of extension methods as influenced by educational levels are as indicated in Table 3. Results indicate that generally most certificate and diploma holders preferred more familiar methods of farm visits and trainings/demonstrations while the masters level holders preferred ICT, trainings/ demonstrations and print media.

The majority of certificate level holders (73\%) preferred to use farm visits as individual methods, a similar percentage $(73 \%)$ preferred trainings and demonstrations as group methods while $45 \%$ preferred field days for mass media methods. 
Creative Commons User License: CC BY-NC-ND

Abstracted by: EBSCOhost, Electronic Journals Service (EJS), Google Scholar, Journal Seek, Scientific Commons,

Food and Agricultural Organization (FAO), CABI and Scopus

http://eoi.citefactor.org/10.11226/v24i2
Journal of Agricultural Extension

Vol. 24 (2) April, 2020

ISSN(e): 24086851; ISSN(Print); 1119944X

http://journal.aesonnigeria.org

http://www.ajol.info/index.php/iae

Email: editorinchief@aesonnigeria.org

Table 3: Extension workers' educational levels and choice of extension methods

\begin{tabular}{lccccc}
\hline & $\begin{array}{c}\text { Certificate } \\
\text { Percentage } \\
\mathrm{n}=11(17.2 \%)\end{array}$ & $\begin{array}{c}\text { Diploma } \\
\text { Percentage } \\
\mathrm{n}=17(26.7 \%)\end{array}$ & $\begin{array}{c}\text { Bachelors } \\
\text { Percentage } \\
\mathrm{n}=26(40.6 \%)\end{array}$ & $\begin{array}{c}\text { Masters } \\
\text { Percentage } \\
\mathrm{n}=10(15.6 \%)\end{array}$ & $\begin{array}{c}\text { Potal } \\
\mathrm{n}=64(100)\end{array}$ \\
\hline $\begin{array}{l}\text { Staff choices of individual } \\
\text { Farm visits }\end{array}$ & 73 & 52 & 35 & 0.0 & 41 \\
& & & & & \\
Office visits & 27 & 24 & 38 & 20 & 30 \\
ICT & 0 & 24 & 27 & 80 & 30 \\
Staff choices for group methods & & & & \\
Train/demos & 73 & 82 & 35 & 80 & 61 \\
Group tours & 27 & 18 & 65 & 20 & 39 \\
Staff choices for mass methods & & & & & \\
Field days & 45 & 64 & 65 & 20 & 55 \\
Print media & 27 & 18 & 27 & 70 & 31 \\
Shows & 27 & 18 & 8 & 10 & 14 \\
\hline
\end{tabular}

Source: Field Survey, 2017.

Most diploma holders also chose to use similar extension methods as the certificate level holders. The Bachelor's Degree holders preferred office visits, group tours and field days, and they were generally comfortable with most of the methods. The workers who held master's education preferred ICT, trainings and demonstrations and print media. These results indicate that the higher the educational level of the extension worker, the more they would diversify in the use of extension methods.

These results concur with the findings of Al-Zahrani, Aldosari, Baig, Shalaby, and Straquadine (2017), indicating that nearly half of the workers had completed secondary level, $35.4 \%$ held a bachelor's degree while $19.3 \%$ held above bachelor's degree level of education. The authors concluded that the higher the educational level of a staff the more competences they held to enhance farmer production by ensuring a steady flow of information dissemination. The appropriate choice of an extension method enhances farmer's production and farmer empowerment.

\section{Choice of Extension Methods by Years of Experience of the Extension Workers}

Results of the choice of extension methods by years of experiences are as indicated in Table 4. These results show that all the workers with less than 5 years of experience chose to use farm visits as compared to ICT and office visits. This was necessitated by the lack of experiences in field conditions. They also preferred to use group tours and shows for group methods and mass media methods respectively. Those workers with experiences of over 5 years to 15 years were generally more comfortable with most methods as opposed to those with over 15 years of experience. 
Creative Commons User License: CC BY-NC-ND

Abstracted by: EBSCOhost, Electronic Journals Service (EJS), Google Scholar, Journal Seek, Scientific Commons,

Food and Agricultural Organization (FAO), CABI and Scopus

http://eoi.citefactor.org/10.11226/v24i2
Journal of Agricultural Extension

Vol. 24 (2) April, 2020

ISSN(e): 24086851; ISSN(Print); 1119944X

http://journal.aesonnigeria.org

http://www.ajol.info/index.php/iae

Email: editorinchief@aesonnigeria.org

Table 4: Extension workers' experiences and choices of extension methods.

\begin{tabular}{|c|c|c|c|c|c|}
\hline & $\begin{array}{l}<5 \text { years } \\
\text { Percentage } \\
n=3(4.7 \%)\end{array}$ & $\begin{array}{l}5<10 \\
\text { years } \\
\text { Percentage } \\
n=19 \\
(29.4 \%)\end{array}$ & $\begin{array}{l}10<15 \\
\text { years } \\
\text { Percentage } \\
n=38 \\
(59.4 \%)\end{array}$ & $\begin{array}{l}\text { Over } 15 \\
\text { years } \\
\text { Percentage } \\
n=4(6.3 \%)\end{array}$ & $\begin{array}{l}\text { Percentage } \\
\mathrm{N}=64 \\
(100 \%)\end{array}$ \\
\hline \multicolumn{6}{|c|}{ Staff choice of individual method } \\
\hline Farm visits & 100 & 20 & 27 & 25 & 40 \\
\hline Office visits & 0 & 18 & 39 & 25 & 30 \\
\hline ICT & 0 & 62 & 34 & 50 & 30 \\
\hline \multicolumn{6}{|c|}{ Staff choice of group method } \\
\hline Train/ demos & 0 & 53 & 68 & 75 & 61 \\
\hline Group tours & 100 & 47 & 32 & 25 & 39 \\
\hline \multicolumn{6}{|c|}{ Staff choice of mass media method } \\
\hline Field days & 0 & 42 & 60 & 100 & 55 \\
\hline Print media & 0 & 47 & 29 & 0 & 31 \\
\hline Shows & 100 & 11 & 11 & 0 & 14 \\
\hline
\end{tabular}

Source: Field Survey, 2017.

These results concur with the findings of Oluwafemi, Olorunfemi and Oladele, (2019) indicating that at an average of 9.35 years of experience extension workers were expected to have enhanced their capacity on implementing issues on climate agricultural initiatives. The implication is that as the workers gained more field experience, they would progress to using diverse methods of extension.

The effectiveness of an extension method is determined by the ability of the worker to employ ALPs to make the method suitable in information dissemination in adult learning.

\section{Extension Worker Awareness of Adult Learning Principles}

The results of extension worker awareness of adult learning principles are shown in Table 5

Table 5: Extension worker awareness of adult learning principles

\begin{tabular}{lccc}
\hline & Fully Aware & Not Aware & Partially Aware \\
& Percentage $(n=5)$ & Percentage $(\mathrm{n}=27)$ & Percentage $(\mathrm{n}=32)$ \\
\hline Male & 1.5 & 15.6 & 1.5 \\
Female & 7.8 & 34.3 & 39.3 \\
Total & 9.3 & 49.9 & 40.8 \\
\hline
\end{tabular}

Source: Field Survey, 2017.

Results indicate that only $9.3 \%$ of the workers (1.5\% male, $7.8 \%$ female) were conversant with the adult learning principles while $49.9 \%$ (15.6\% male, $34.3 \%$ female) of the extension workers were not aware of the principles and therefore did 
Creative Commons User License: CC BY-NC-ND

Abstracted by: EBSCOhost, Electronic Journals Service (EJS), Google Scholar, Journal Seek, Scientific Commons,

Food and Agricultural Organization (FAO), CABI and Scopus
Journal of Agricultural Extension

Vol. 24 (2) April, 2020

ISSN(e): 24086851; ISSN(Print); 1119944X

http://journal.aesonnigeria.org

http://www.ajol.info/index.php/iae

Email: editorinchief@aesonnigeria.org

not apply them in their choice and use of extension methods. The results also revealed that while $40.8 \%$ of the workers (1.5\% male, $39.3 \%$ female) were either partially aware of the principles or were not aware of their applications in the choice of the extension methods.

These results concur with the findings of Okoedo-Okojie and Edeoghon (2017), that few extension principles were practiced by the extension workers as result of their background disciplines. The importance of using a different paradigm in adult information dissemination by application of ALPs for empowerment in adoption was emphasised by Ferreira and Maclean (2017).

\section{Influence of Extension Worker Characteristics on Empowerment of Farmers}

The multiple regression model run with all four social-economic predictors produced an $R^{2}=0.372(p<0.5)$, indicating that $37.2 \%$ of farmer empowerment was explained by gender, age, educational levels and work experiences of the extension worker. Although the multiple linear regression model explanatory power of $37.2 \%$ was not strong enough, the statistical significance and positive influence of the extension worker characteristics on UPA farmer empowerment is an important finding. The influence of the characteristics of extension workers as indicated in Table 6 were significant $(p<0.5)$ to the empowerment of UPA farmers.

Table 6: Extension worker characteristics and empowerment of farmers

\begin{tabular}{lccc} 
& \multicolumn{2}{c}{ Coefficients } & \\
\cline { 2 - 3 } & $\mathrm{B}$ & Std. Error & $\mathrm{t}$ \\
\hline (Constant) & 1.328 & 0.536 & 2.477 \\
Gender of extension worker & 0.424 & 0.206 & 2.062 \\
Age of extension worker & 0.266 & 0.120 & $2.223^{*}$ \\
Education of extension & 0.217 & 0.098 & $2.206^{*}$ \\
worker & 0.186 & 0.073 & 2.532 \\
Years of experience & &
\end{tabular}

$\mathrm{P} \leq 0.5$ a. Dependent Variable: Empowerment score

The results on Table 6 indicate that a unit increase in considerations of age, educational levels, and years of experience of the extension worker would yield positive changes in the empowerment of the farmers. All extension worker characteristics indicated positive contributions in the empowerment of farmers. These results indicate that improving the capacities of all workers would contribute to empowering the farmers. This can be achieved by capacity building of staff by refresher short courses. This can also be achieved through trainings and workshops on how staff can apply ALPs in their choices off extension methods which would contribute to farmer's empowerments. These results concur with the findings of a report by Abubakar, Atala, Abdullahi, Abdullahi, (2019) on the importance of continuously capacity building staff on specific issues to enhance performance. 
Creative Commons User License: CC BY-NC-ND

Abstracted by: EBSCOhost, Electronic Journals Service (EJS), Google Scholar, Journal Seek, Scientific Commons,

Food and Agricultural Organization (FAO), CABI and Scopus
Journal of Agricultural Extension

Vol. 24 (2) April, 2020

ISSN(e): 24086851; ISSN(Print); 1119944X

http://journal.aesonnigeria.org

http://www.ajol.info/index.php/iae

Email: editorinchief@aesonnigeria.org

\section{Conclusions and Recommendations}

The socio-economic characteristics of the extension workers significantly and positively influenced the choice of extension methods. Most of the extension workers were not aware of the adult learning principles and did not utilize them in their extension practice.

There is need for specific capacity building of extension workers, considering their socio-economic characteristics on awareness and use of ALPs and ICT as a method of information dissemination for urban farmers. This can be achieved by Nairobi City County Government in collaboration with higher education institutions and other relevant stakeholders.

\section{References}

Abubakar, L., Atala, T.K., Abdullahi, H.A. and Abdullahi, J.A. (2019). Data management capabilities of extension personnel in Kaduna Agricultural Development Agency, Kaduna State Nigeria. Journal of Agricultural Extension. Vol 23(4):27-28.

Al-Zahrani, K.H., Aldosari, F.O., Baig, M.B., Shalaby, M.Y. and Straquadine, G.S. (2017). Assessing the competencies and training needs of agricultural extension workers in Saudi Arabia. Journal of Agricultural Science and technology.Vol.13:33-46.

Chihambakwe, M., Mafongoya, P. and Obert, J. (2018). Urban and peri urban agriculture as a pathway to food security: A review mapping the use of food sovereignty. Journal challenges 2019.Vol10 (6):3.

Dika, H., Masawe, E., Iddi, S. and Rumanyika, R. (2017). Plasma haemoglobin concentrations among pregnant and non-pregnant women in Mwanza: Are we using correct reference values to diagnose anaemia pregnancy? The Pan African Medical Journal 30 (93):3

Etikan, I., Musa, A. and Alkassin, R. S. (2015). Comparison of convenience sampling and purposive sampling. American Journal of Theoretical and Applied Statistics. Vol $5(1): 3-4$

Ferreira, D. and Maclean, G. (2017). Andragogy in the $21^{\text {st }}$ century: Applying the assumptions of adult learning online. Language research Bulletine, 32, ICU Tokyo.

ljeoma, M. C. and Adesope, O.M. (2015). Effects of personality types of extension personnel on their job performance in Rivers State Agricultural Development Programme. Journal of Agricultural Extension. Vol19 (1) 94-95

Kenya National Bureau of Statistics (2019). 2019 Kenya population and housing census Vol1:7. Government Printers.

Lamontagne-Godwin, J., Cardey, S., Williams, F.E., Dorward, P.T., Aslam, N. and Almas, M. (2019) Identifying gender-responsive approaches in rural advisory services that contribute to the institutionalization of gender in Parkistan. The Journal of Agricultural Education and Extension.Vol 25(3) 273. 
Creative Commons User License: CC BY-NC-ND

Abstracted by: EBSCOhost, Electronic Journals Service (EJS), Google Scholar, Journal Seek, Scientific Commons,

Food and Agricultural Organization (FAO), CABI and Scopus
Journal of Agricultural Extension

Vol. 24 (2) April, 2020

ISSN(e): 24086851; ISSN(Print); 1119944X

http://journal.aesonnigeria.org

http://www.ajol.info/index.php/iae

Email: editorinchief@aesonnigeria.org

Malgorzata R. (2017). Impact of employee age on the safe performance of production tasks. MATEC web of Conferences 94. Retrieved March 23, 2020 from creative commons database

Mbugua, J.N. (2018, May 5). Extension services: Just where did the rain start beating us? Smart harvest, Standardmedia.co.ke

Kenya. Ministry of Agriculture Livestock and Fisheries (MOALF) (2017). Guidelines and standards for agricultural extension and advisory services. Government Printers Nairobi.

Kenya. Nairobi County Annual Development Plan (NCADP) (2018), 2017/2018.Goverment Printers Nairobi.

Kenya. Nairobi County Integrated Development Plan (NCIDP) 2018. Government Printers. Nairobi.

Okoedo-Okojie, D.U. and Edeoghon, C.O. (2017). Application of agricultural extension principles to information dissemination among extension workers in Delta State, Nigeria: implications for urban agriculture. Journal of Biology, Agriculture and Healthcare, 7(12), 6-13

Olorunfemi, T.O., Ololufemi, O.D. and Oladele, O.I. (2019). Determinants of the involvement of extension agents in disseminating climate smart agricultural initiatives: implications for scaling up. Journal of Saudi Society of Agricultural Sciences. (In press) Sciencedirectassests.com 3-4.

Omair, A. (2016). Selecting the appropriate study design for your research: Descriptive study designs. Journal of health specialities. Vol3(3) 153-156

Suvedi, M. and Kaplowitz, M. (2016). What every extension worker should know. Core competency handbook. MEAS.MSUMEAS2016ExtensionHndbkSuvedi

Taguchi, M. and Santini, G. (2019). Urban agriculture in the global North and South: A perspective from FAO. The Veolia Institute Review. Issue 20:12-17. 